\title{
STUDY ON MINERALOGY AND CHEMISTRY OF THE SAPROLITIC NICKEL ORES FROM SOROAKO, SULAWESI, INDONESIA: IMPLICATION FOR THE LATERITIC ORE PROCESSING
}

\author{
Sufriadin $* 1,2$, Arifudin Idrus ${ }^{2}$, Subagyo Pramumijoyo ${ }^{2}$, I Wayan Warmada ${ }^{2}$, and Akira \\ Imai $^{3}$ \\ ${ }^{1}$ Mining Engineering Study Program, Hasanuddin University, Makassar 90245, Indonesia \\ ${ }^{2}$ Department of Geological Engineering, Gadjah Mada University, Yogyakarta 55281, Indonesia \\ ${ }^{3}$ Department of Earth Science and Technology, Akita University, Akita 010-8512, Japan
}

\begin{abstract}
An investigation of mineralogy and chemistry of saprolitic nickel ores developed on ultramafic rock with different serpentinization degree from Soroako, Sulawesi has been conducted using $X$ ray diffraction, thermal analysis, FTIR, and ICP-AES. The implication for the processing of these ores under acidic media was also studied. Weathering of unserpentinized peridotite in the Soroako west block produces saprolitic ore containing minerals such as relict olivine, goethite, quartz, talc with minor serpentine and smectite; whereas the weathered materials overlaying serpentinized peridotite in the Petea area are mainly composed of residual serpentine with lesser chlorite, maghemite, and remnant pyroxene and amphibole. Chemical analysis determined by ICP-AES demonstrates that west ore is higher in $\mathrm{Si}, \mathrm{Mg}$, and Ni, as compared to that Petea ore. Conversely, Fe and Al concentrations are higher in Petea ore than in west block ore. SEM-EDX examination reveals that olivine, talc, serpentine and goethite are the Ni-bearing phases occurring in west block ore; while serpentine is the principal host for $\mathrm{Ni}$ in the Petea ore. Chemical leaching under sulfuric acid reveals that olivine has highest dissolution rate in the
\end{abstract}

*Corresponding author: SUFRIADIN, Mining Engineering Study Program, Hasanuddin University, Makassar 90245, Indonesia. E-mail: sufriadin_as@yahoo.com west ore followed by serpentine; while talc, pyroxene, and iron oxides have slow dissolution rates. In contrast, serpentine in Petea ore is easily dissolved and is followed by chlorite; whereas amphibole, pyroxene, and maghemite are difficult to leach. Quartz is present in both ores and it seems to be undissolved during the chemical leaching. It is shown that $\mathrm{Ni}$ recovery from Petea saprolitic ore is higher than that of West Block ore.

Key words: Serpentine, SEM/EDX, talc, nickel.

\section{Introduction}

Lateritic weathering and supergene nickel enrichment developed on ultramafic rock has been studied extensively in many part of the world (Schellmann, 1989; Barros de Olievera et al., 1992; Gleeson et al., 2004; Thorne et al., 2009). Characteristic of the laterite ore resulting from chemical weathering of these rocks are influenced by the nature of parent rock, climatic condition, topography, and time (Freyssinet et al., 2005). The nature of bedrock protolith particularly serpentinization degree is found to have significant role in the development of commercially Ni laterite deposit. Golightly (1981) suggested that nickel laterite ore derived from unserpentinized ultramafic rock is commonly characterized by thinner saprolite, many 
boulder, but higher in $\mathrm{Ni}$; while the weathering of serpentinized ultramafic protolith tends to produce thicker saprolite but lower $\mathrm{Ni}$ content. Weathering process of ultramafic rock concentrates $\mathrm{Ni}$ in the two principal mineralization zones (Luo et al., 2009): limonitic laterite which lies in the upper part of the profile and saprolitic laterite which is located in lower part of the profile or just above of unaltered ultrabasic rock. In general, lateritic nickel ores may be classified into three types based on the domination of Ni bearing minerals (Brand et al., 1998; Elias, 2002): (1) hydrous Mg silicate ore (type A) with garnierite is the dominant Ni host, (2) clay silicate ore (type B) with smectite (e.g. nontronite) as principal Ni host, and (3) oxide ore in which is dominated by goethite.

Currently, two processes can be employed for extracting the Ni from lateritic ores: pyrometallurgy (smelting), producing nickel matte and ferronickel and hydrometallurgy (leaching), producing both $\mathrm{Ni}$ and $\mathrm{Co}$. The choice between pyrometallurgical and hydrometallurgical processing depends on mineralogical characteristic and chemical dissemination of the ore. Due to the continuously depleting of global Ni-sulfide ore and high energy requirement associated with the $\mathrm{Ni}$ extraction by smelting, leads to increase the research interest in the recovery of $\mathrm{Ni}$ and (Co) from nickel laterite ore by leaching.

Mineralogical characterization of the nickel laterite ore is essential step that should be performed before the application of process option. Soroako nickeliferous laterite deposit is the most important ore as source for $\mathrm{Ni}$ in Indonesia. Despite this deposit has been produced for nearly four decades, the information on its mineralogical characteristic is minimal. The present paper discusses the mineralogy and chemistry of saprolitic Ni ores from Soroako, Sulawesi and its implication for lateritic Ni ore processing by leaching experiment under acidic media.

\section{Location and Geological Setting}

Soroako nickeliferous laterite deposit is located about $40 \mathrm{~km}$ from Malili, a capital city of East Luwu regency or around $600 \mathrm{~km}$ from
Makassar, a provincial city of South Sulawesi to the northeast (Figure 1). This deposit is resulted from the intensively chemical weathering of the Cretaceous ultramafic rocks that is included in the East Sulawesi Ophiolite (ESO). This ophiolite is tectonically dismembered and cropped out over than $10,000 \mathrm{~km}^{2}$ in the eastern Sulawesi (Monnier et al., 1995). Peridotite around Soroako is petrologically dominated by by harzburgitic-peridotite with higher in Cr\# (Kadarusman et al., 2004). However, lherzolite and locally dunite are also present. Elsewhere in the Soroako area, the bedrock is essentially unserpentinized where serpentine being only restricted to border of joints as thin rim or as fine grained matrix of tectonic breccias (SoeriaAtmadja et al., 1974).

The multiple tectonic events have occurred from Paleogene to Neogene (Dirk, 2001) within this area. These have led to the formation of at least three regional sinistral strike-slip faults hitting this complex: Matano Fault is in the north followed by Lawanopo trend in the center and Kolaka Fault in south. Matano Fault which is run from the Tolo Gulf in the east and merged with Palu Koro Fault in the west, seems to have significant role in the development of laterite in this area (Ahmad, 2005).

\section{Methods}

\section{Samples}

Two representative samples used in this study were collected from Soroako mining district (Figure 1). Each sample represents a composite material from three saprolitic horizons. Sample west ore (WO) was derived from lateritic ore that has been formed over unserpentinized peridotite of West Block; whereas the east ore (EO) sample was taken from Petea area which is typically covered by serpentinized peridotite. After drying at $100^{\circ} \mathrm{C}$ for 1 hour, samples were ground with agate mortar and vibrating mill, followed by sieving to $-100 \#(<0.15 \mathrm{~mm})$.

\section{Analytical techniques}

X-ray diffraction (XRD) analysis was performed by a Rigaku RINT 2000 and RIGAKU Multiflex 


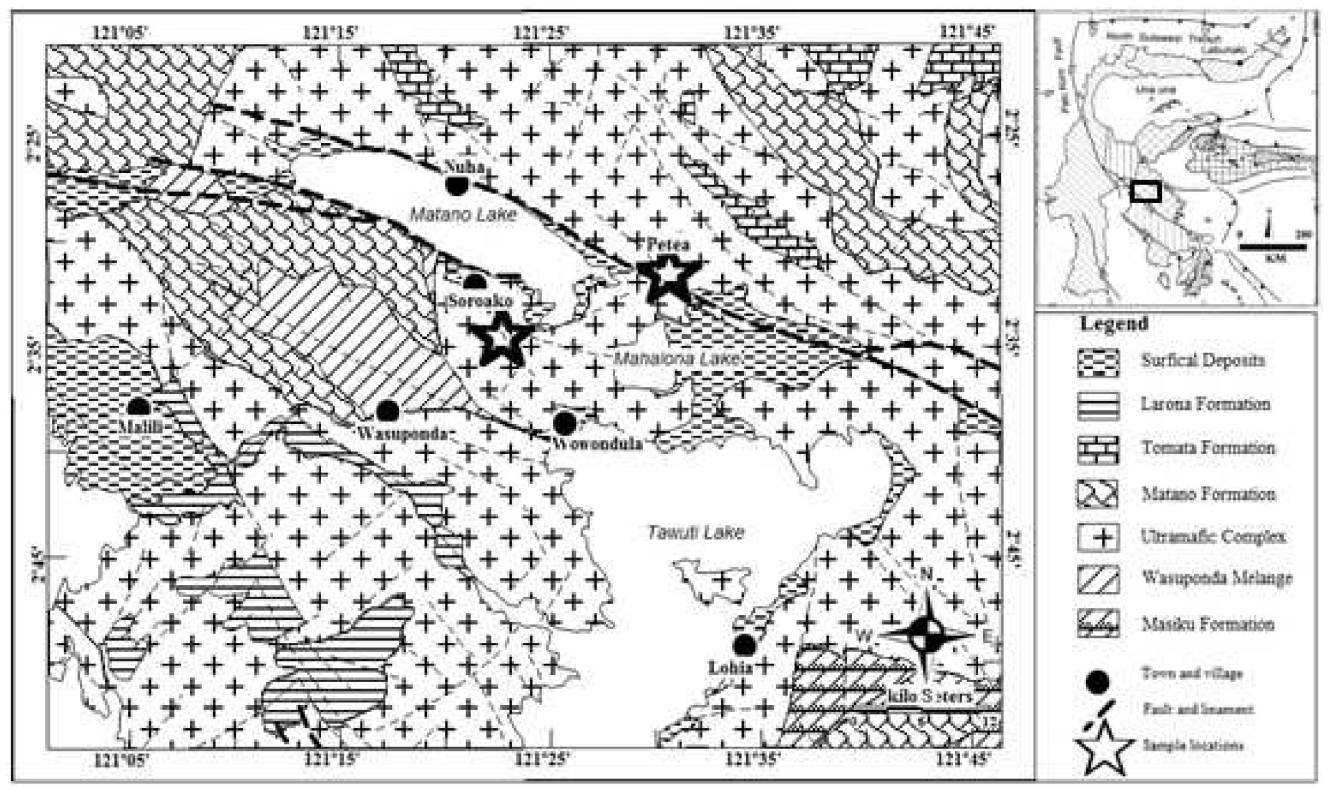

Figure 1: Geological map of Soroako mining district, Sulawesi. Stars indicate sample locations

$\mathrm{X}$ ray diffractometer $(\mathrm{Cu}-\mathrm{K} \alpha$ radiation, $\lambda=1.541)$ with the voltage of $40 \mathrm{kV}$ and current at 20 $\mathrm{mA}$. The patterns of diffraction were obtained by scanning random powder mounts from 2 $65^{\circ} 2 \theta$, scanning step at $0.02^{\circ}$ and counting time $2^{\circ} /$ minute. For clay analysis, three times scanning from 2 to $40^{\circ} 2 \theta$ were employed including air-dry, ethylene glycol salvation, and heating to $550^{\circ} \mathrm{C}$. Phase identification and semiquantitative proportion of minerals contained in the samples were executed by MATCH! 1.10 software.

For TG/DTA analysis, about $20 \mathrm{mg}$ powder sample placed in platinum crucible was analyzed by a simultaneous differential thermal analyzer (SSC/5200 SII-SEIKO Instrument). Data were collected in air atmosphere with flow rate at $20 \mathrm{~mL} / \mathrm{min}$, temperature range of 27 $1000^{\circ} \mathrm{C}$, heating rate $10^{\circ} \mathrm{C} / \mathrm{min}$ and calcined $\mathrm{Al}_{2} \mathrm{O}_{3}$ used as inert substance.

The infrared analysis of these samples was also carried out to interpret the molecular structure of minerals present. A mixture about 2 $\mathrm{g}$ samples and $200 \mathrm{~g} \mathrm{KBr}$ was prepared for pressed disks. The disk then was scanned under absorbance mode within the range frequencies of $4000-400 \mathrm{~cm}^{-1}$ by means of JUSCO FTIR spectrometer. Chemical analysis was conducted under digestion samples using ICP-
AES, while chemical composition of individual mineral was determined under carbon coated materials by SEM-EDX spectrometer.

\section{Leaching experiment}

Leaching tests were conducted in batch reactor using a $250 \mathrm{ml}$ glass beaker. For each run, the slurry was prepared by the mixture of 10 g dried ore sample with $50 \mathrm{ml}$ of a $25 \%$ sulfuric acid solution. It was then heated at the temperature of $90^{\circ} \mathrm{C}$ with the agitating speed at $500 \mathrm{rev} / \mathrm{min}$ using REXIM RSH-1A magnetic stirrer. The leaching time was set for 30 to 180 minutes with an interval of 30 minutes. Separation of solid residues with leached solution was made by using a $0.45 \mu \mathrm{m}$-sized of membrane filter. Residues were washed with distilled water for several times, dried at $100^{\circ} \mathrm{C}$ for 2 hours, and analyzed with XRD, SEM-EDX, and FTIR. Chemical composition of leached solutions was determined by ICP-AES.

\section{Results and Discussion}

\section{Mineralogical studies}

The patterns of X-ray diffraction of two saprolitic ore samples are given in Figure 2. Minerals identified in the studied samples var- 
ied from primary to secondary sheet silicates and lastly to iron oxi-hydroxides (Table 2). Forsterite $\left(\mathrm{Mg}_{2} \mathrm{SiO}_{4}\right)$, enstatite $\left(\mathrm{MgSiO}_{3}\right)$ and trace amount of spinel are the primary mineral occurring in west block ore. Secondary minerals detected in this sample are principally quartz $(3.14 \AA)$ with lesser amounts of serpentine $(7.32 \AA)$ and talc $(9.38 \AA$ ) (Figure 2a). In the sample $\mathrm{EO}$, the most intense reflections that occurred at $7.308 \AA$ and $3.655 \AA$ are diagnostic peaks of lizardite- $1 \mathrm{M}\left[(\mathrm{Mg}, \mathrm{Fe}) 3 \mathrm{Si}_{2} \mathrm{O}_{5}(\mathrm{OH})_{4}\right]$, a serpentine end-member (Figure $2 \mathrm{p}$ ). Other secondary minerals that coexist with lizardite are chlorite $(14.20 \AA)$, goethite $(4.20 \AA)$, magnetite/maghemite $(2.51 \AA)$, and quartz ( $3.34 \AA)$; while the primary residual minerals such as enstatite $(2.88 \AA)$ and amphibole $(8.43 \AA)$ are also present in small amounts. Talc in which only detected in sample WO is inferred to be more residually material derived from primary talc of the parent rocks. It is originally formed by hydrothermal alteration of enstatite and/or olivine was relatively more resistant during chemical weathering. However, $\mathrm{Ni}^{2+}$ substitutions for $\mathrm{Mg}^{2+}$ within crystal structure of talc may be possible. Other Ni-bearing phases found in west ore sample are olivine, serpentine, and iron oxide. In the case of Petea ore (EO) sample, lizardite is likely the principal $\mathrm{Ni}$ bearing mineral but chlorite and amphibole could also be the carrier for nickel.

DTA curve of west ore sample (Figure 3A) can be divided into two parts: (1) low temperature region $\left(<400^{\circ} \mathrm{C}\right)$ and (2) high temperature region $\left(400-800^{\circ} \mathrm{C}\right)$. In low temperature region the curve shows endothermic reaction at about $250{ }^{\circ} \mathrm{C}$. This peak corresponds to the loss of adsorbed water in two steps as illustrated in TG curve (dashed line in Figure $3 \mathrm{~A}$ ). In high temperature region, the broad endothermic peak occurs at about $570^{\circ} \mathrm{C}$ and it reached maximum at around $805^{\circ} \mathrm{C}$. These peaks relate to the loss of hydroxyl water. The short exothermic maximum occurs at about $825^{\circ} \mathrm{C}$ that might be linked to crystallization of hydrous minerals such as serpentine and talc. The relatively elevated temperature of exothermic peak in low temperature reactions may be due to the higher proportion of anhydrous miner- als are present in sample such as forsterite and quartz. In the east ore sample (EO), TG/DTA curves show two endothermic peaks in lower temperature region (Figure $3 \mathrm{~B}$ ). The first and second endothermic peak within this region occurs at $80^{\circ} \mathrm{C}$ and $260^{\circ} \mathrm{C}$ corresponding to the loss of adsorbed and bound water respectively. In the higher temperature region, the strong endothermic peak at about $560^{\circ} \mathrm{C}$ may be related to the loss of hydroxyl water and the weight loss is completed around $800^{\circ} \mathrm{C}$. Above this temperature, DTA curve shows sharp exothermic peak, indicating a complete recrystallization.

Infrared spectra of WO and EO samples show two absorption bands appeared in the range of $3700-3200 \mathrm{~cm}^{-1}$ (Figure 4). The bands at 3676 and $3683 \mathrm{~cm}^{-1}$ can be attributed to stretching vibrations of hydroxyls bonded to magnesium atom in octahedral layer (Liu et al., 2010). The wide absorption bands at 3427 and $3433 \mathrm{~cm}^{-1}$ were assigned to hydroxyl bonded to trivalent cations (e.g. $\mathrm{Fe}^{3+}$ or $\mathrm{Al}^{3+}$ ) in octahedral coordination (Fuchs et al., 1998). Absorption bands in the region $1100-700 \mathrm{~cm}^{-1}$ can be related to different vibrations of $\mathrm{Si}-\mathrm{O}$ bond in tetrahedron. The band at $1009 \mathrm{~cm}-1$ with shoulders at 1036 $\mathrm{cm}-1$ and $985 \mathrm{~cm}^{-1}$ observed in EO sample may be originated from $\mathrm{Si}-\mathrm{O}$ in-plane stretching vibration. Likewise the strong band at 1009 with weak bands at 887 and $791 \mathrm{~cm}^{-1}$ in WO sample may also be arisen by Si-O bonds linked with trivalent cation. The absence of bands around $800-700 \mathrm{~cm}^{-1}$ in the EO sample indicate the lesser amounts of free silica content compared to the WO sample. In the $700-400 \mathrm{~cm}^{-1}$ regions, the bands at $661 \mathrm{~cm}^{-1}, 625 \mathrm{~cm}^{-1}$, and $615 \mathrm{~cm}^{-1}$ can be attributed to deformation of $\mathrm{Mg}^{2+}-\mathrm{O}-\mathrm{H}$ bonds (Sontevska et al., 2007). This deformation may be linked to the substitution of iron, nickel or aluminum. The strong bands around $550-400 \mathrm{~cm}^{-1}$ are due to the Si-O-Si bending vibration.

\section{Chemical composition}

Results of chemical analysis of two ore samples are shown in Table 1. The concentrations of $\mathrm{SiO}_{2}$ and $\mathrm{MgO}$ in sample $\mathrm{WO}$ are higher than that in sample EO. These values are con- 


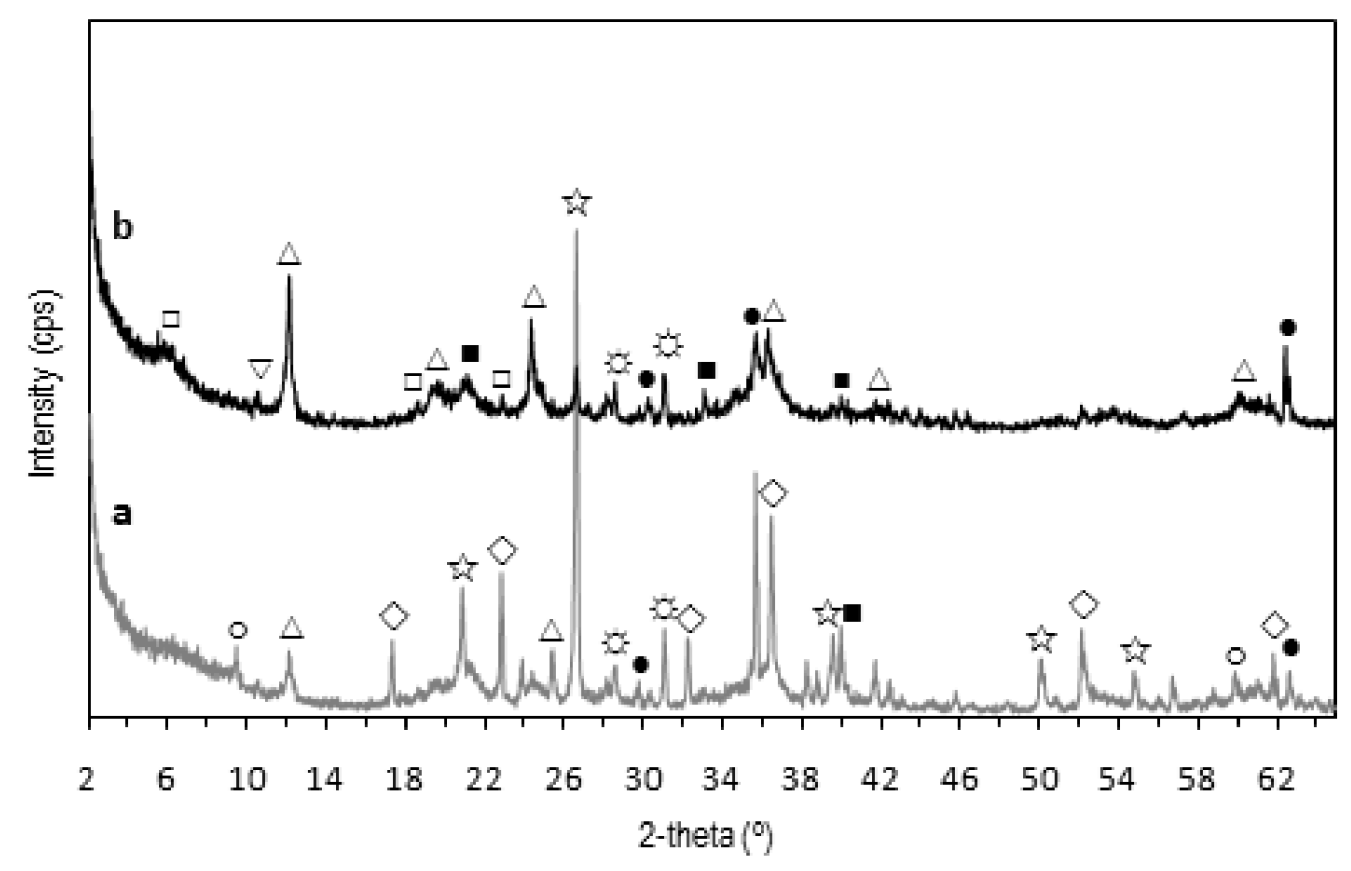

Figure 2: X-ray diffraction patterns of saprolitic ore samples from Soroako west block (a) and Petea area (b). Notes: $+=$ serpentine (lizardite), $\star=$ quartz, $\square=$ chlorite, $\bullet=$ maghemite $/$ magnetite, $\diamond=$ forsterite, $\bigcirc=$ talc, $=$ enstatite, $\nabla=$ amphibole
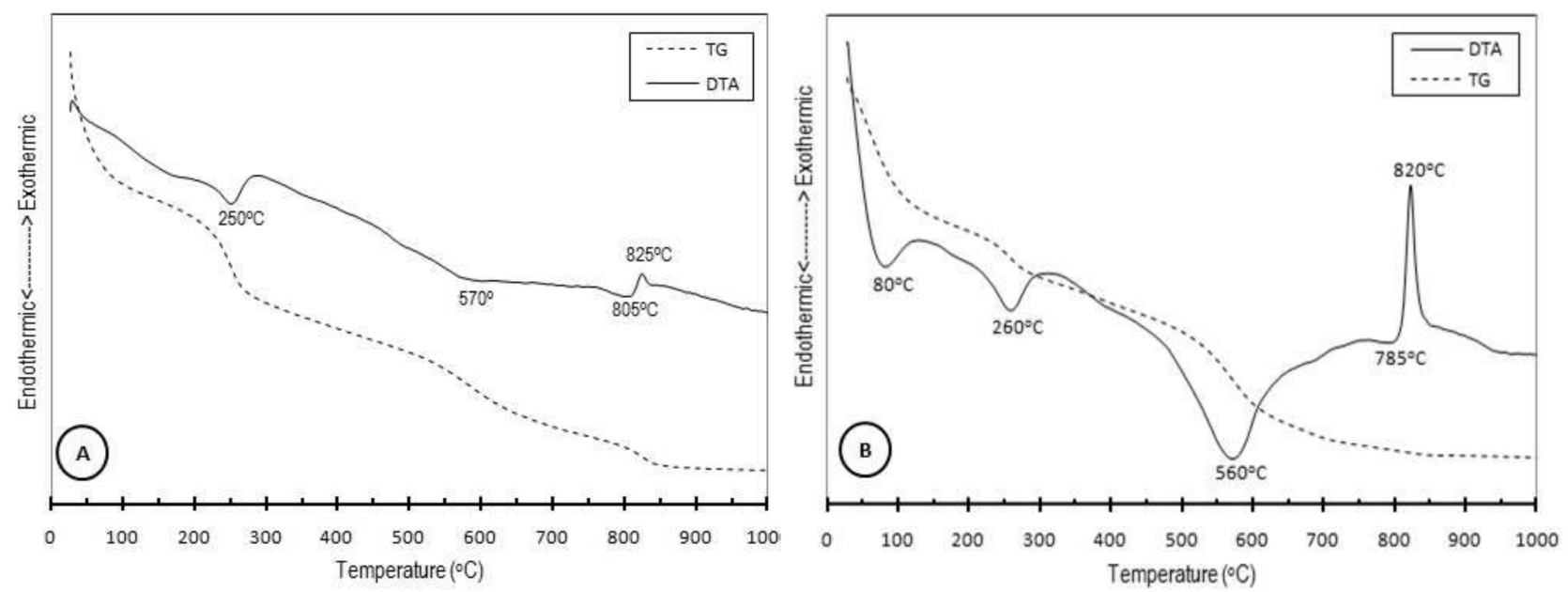

Figure 3: TG/DTA curves of ore sample (WO) from Soroako west block (A) and east ore (EO) from Petea area $(\mathrm{B})$ 
sistent with the higher proportion of quartz and forsterite in sample WO as determined by XRD method. This feature is also supported by FTIR data as shown in Figure $4 . \mathrm{Fe}_{2} \mathrm{O}_{3}$ and $\mathrm{Al}_{2} \mathrm{O}_{3}$ concentrations show higher value in sample EO as compared to that in sample WO. Iron in sample EO is not only occurred as compounds in maghemite and goethite but it also likely appears to be incorporated into octahedral coordination of serpentine/lizardite and chlorite structures. Similarly, Al might also be present as adsorbed or substituted element within goethite and serpentine structure.

Nickel content in sample EO is slightly lower than that in sample WO. It is expected that, $\mathrm{Ni}$ in sample EO is mainly hosted in lizardite, while in sample $\mathrm{WO} \mathrm{Ni}$ is probably associated with talc serpentine, goethite, and olivine. Concentrations of $\mathrm{Mn}, \mathrm{Co}$, and $\mathrm{Zn}$ are relatively similar for both ore samples. The content of $\mathrm{Cr}$ in the sample EO is higher than that in sample WO. Chromium is mainly present in spinel, lesser in goethite, and trace amounts in pyroxene.

\section{Dissolution of minerals in the ores}

The strongest reflections at $5.12 \AA, 3.72 \AA$, and $1.75 \AA$ observed in sample WO (Figure 2) that belong to forsteritic olivine, disappeared in solid residues. Disappearance of such peaks indicates complete dissolution of forsterite in sulphuric acid. Serpentine also seems to be readily dissolved in sample WO which is shown by the weakness of basal reflection in solid residue for 30 minutes leaching and dissappears after 150 minutes reaction. However, the existence of stronger reflection lines of other phases such as quartz, talc, enstatite, and iron oxides in solid residues exhibit that these phases were difficult to dissolve in sulphuric acid solution.

The strongest lines of lizardite at $7.31 \AA$ and $3.65 \AA$ in Petea ore sample were substantially reduced in leach residues. The basal spacing at $7.308 \AA$ in raw ore sample reduced to $7.132 \AA$ in solid residue after leaching for 150 minutes. These indicated that lizardite was easily reacted with sulphuric acid. Although reflections of spinel and/or goethite seem to be collapsed in leach residue, it is prossibly dis- solved slowly. However, the peaks of minerals such as quartz, enstatite and amphibole remain strong in leached residues. This reveals that these minerals were rather difficult to leach in sulphuric acid. Table 2 shows the semi quantitative mineral in solid residues under different leaching time determined by XRD.

The overall results of leaching experiments (Table 2) indicate that minerals such as quartz, enstatite and talc in the west ore (WO) are the most difficult to leach in sulphuric acid. On the other hand, minerals such as quartz, enstatite and amphibole from Petea ore are very hard to dissolve in sulphuric acid. Nearly all olivine and serpentine in the west block sample dissolved in sulphuric acid after 30 minute leaching, indicating congruent dissolution. However, serpentine in the east ore sample seems not to be completely dissolved and is usually called incongruent dissolution.

FTIR analysis of two solid residues after leaching at 150 minutes (Figure 5) show disappearance of the bands at 3676 and $3683 \mathrm{~cm}^{-1}$ in sample $\mathrm{WO}$ and $\mathrm{EO}$ respectively indicating decomposition of octahedral layer. The strong bands at $1066 \mathrm{~cm}^{-1}$ with shoulder at $1109 \mathrm{~cm}^{-1}$ followed by medium band at 793 in sample WO suggest that silica was produced from dissolution of minerals such as olivine and serpentine. Likewise, the bands around $1200-1100 \mathrm{~cm}^{-1}$ region and medium band at $793 \mathrm{~cm}^{-1}$ also appear in sample EO. This evidence is consistent with XRD data.

According to Wolff-Boenisch et al. (2006), dissolution rate of silicate minerals could be related to the number of $\mathrm{Si}-\mathrm{O}$ bond present and degree of polimerization. For example, crystal structure of forsterite is formed by a number of isolated $\mathrm{Si}-\mathrm{O}$ tetrahedra which is linked by Mg$\mathrm{O}$ octahedra. Forsterite has non bridging oxygen so that there is no $\mathrm{Si}-\mathrm{O}$ polimerization exist in its structure. In contrast, quartz has structure with three-dimentionally polimerized, implying that all $\mathrm{Si}-\mathrm{O}$ tetrahedra are connected to each other. Hence, forsterite would has faster dissolution rate than quartz.

The octahedral $\mathrm{Mg}-\mathrm{O}$ bonds break more quickly than tetrahedral $\mathrm{Si}-\mathrm{O}$ bonds in layer silicates (Saldi et al., 2007). This evidence re- 
Table 1: Chemical composition of two saprolitic ore samples from Soroako nickeliferous laterite deposit

\begin{tabular}{lrrrrrrrrrr}
\hline Ore sample & $\mathrm{SiO}_{2}$ & $\mathbf{M g O}$ & $\mathrm{Fe}_{2} \mathrm{O}_{3}$ & $\mathbf{M n O}$ & $\mathrm{Al}_{2} \mathrm{O}_{3}$ & $\mathbf{C r}$ & $\mathbf{N i}$ & $\mathbf{C o}$ & $\mathbf{Z n}$ & LOI \\
\hline East ore (EO) & 38.87 & 15.45 & 24.97 & 0.59 & 3.82 & 0.82 & 1.77 & 0.02 & 0.22 & 12.05 \\
West ore (WO) & 49.24 & 23.21 & 15.78 & 0.61 & 1.03 & 0.39 & 2.13 & 0.02 & 0.34 & 7.23 \\
\hline
\end{tabular}

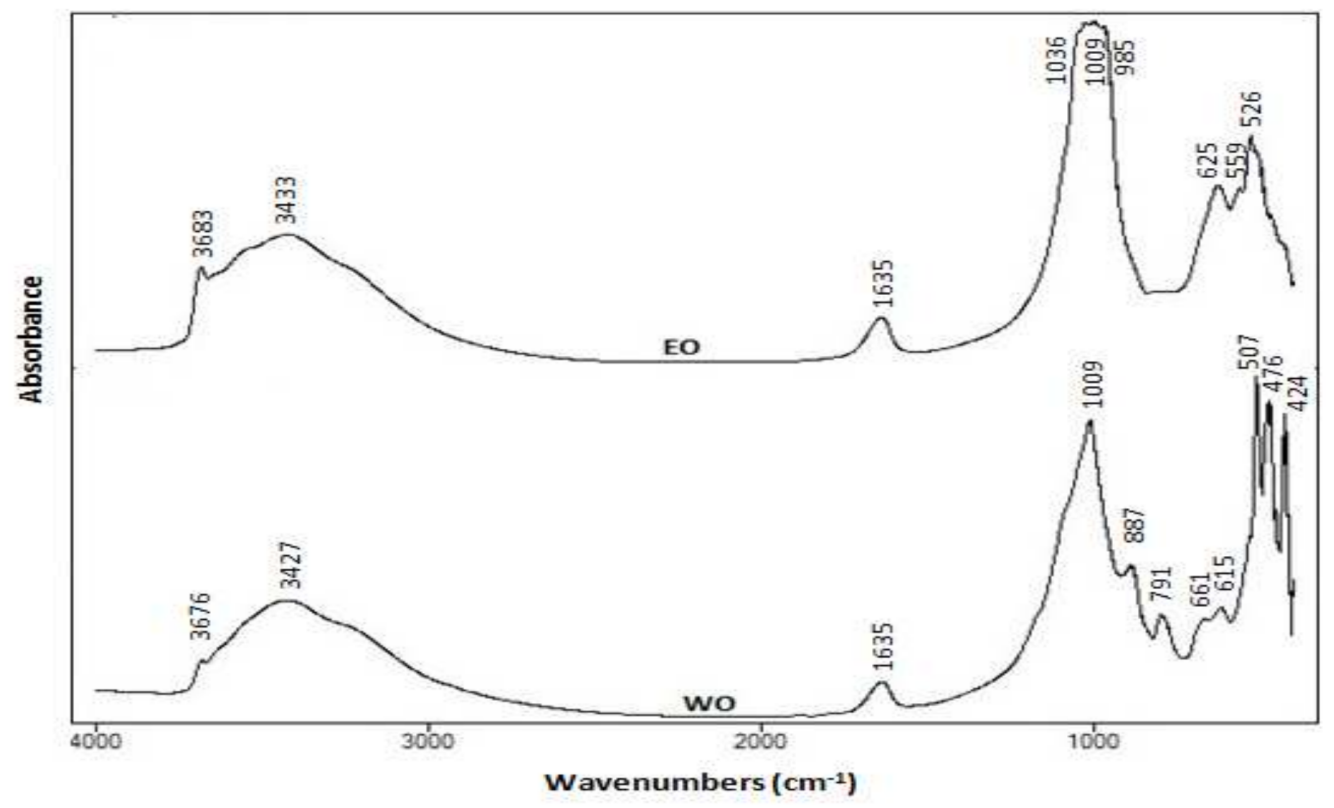

Figure 4: Infrared spectra of west ore (WO) and east ore (EO) samples used in the experiment

Table 2: Semiquantitative mineralogy in ore samples and solid residues after leaching at different time

\begin{tabular}{|c|c|c|c|c|c|c|c|}
\hline \multirow{2}{*}{ Phases } & \multirow{2}{*}{$\begin{array}{l}\text { Raw ore } \\
\text { (wt \%) }\end{array}$} & \multicolumn{6}{|c|}{ wt $\%$ of phases in different leaching time (minutes) } \\
\hline & & 30 & 60 & 90 & 120 & 150 & 180 \\
\hline & & \multicolumn{6}{|c|}{ West ore (WO) } \\
\hline Forsterite & 38 & 9 & - & - & - & - & - \\
\hline Serpentine & 6 & 17 & - & - & - & - & - \\
\hline Enstatite & 17 & 24 & 29 & 24 & 31 & 32 & 33 \\
\hline Quartz & 23 & 35 & 48 & 54 & 60 & 52 & 48 \\
\hline Talc & 10 & 12 & 21 & 18 & 6 & 15 & 17 \\
\hline \multirow[t]{2}{*}{ Spinel/Goethite } & 3 & 3 & 2 & 4 & 3 & 1 & 2 \\
\hline & & \multicolumn{6}{|c|}{ East ore (EO) } \\
\hline Serpentine & 54 & 31 & 18 & 8 & 8 & 8 & 10 \\
\hline Enstatite & 22 & 40 & 42 & 34 & 47 & 50 & 46 \\
\hline Quartz & 4 & 9 & 11 & 16 & 12 & 17 & 12 \\
\hline Amphibole & 15 & 14 & 29 & 35 & 29 & 22 & 30 \\
\hline Maghemite & 4 & 6 & - & 7 & 4 & 3 & 4 \\
\hline Chlorite & 1 & - & - & - & - & - & - \\
\hline
\end{tabular}




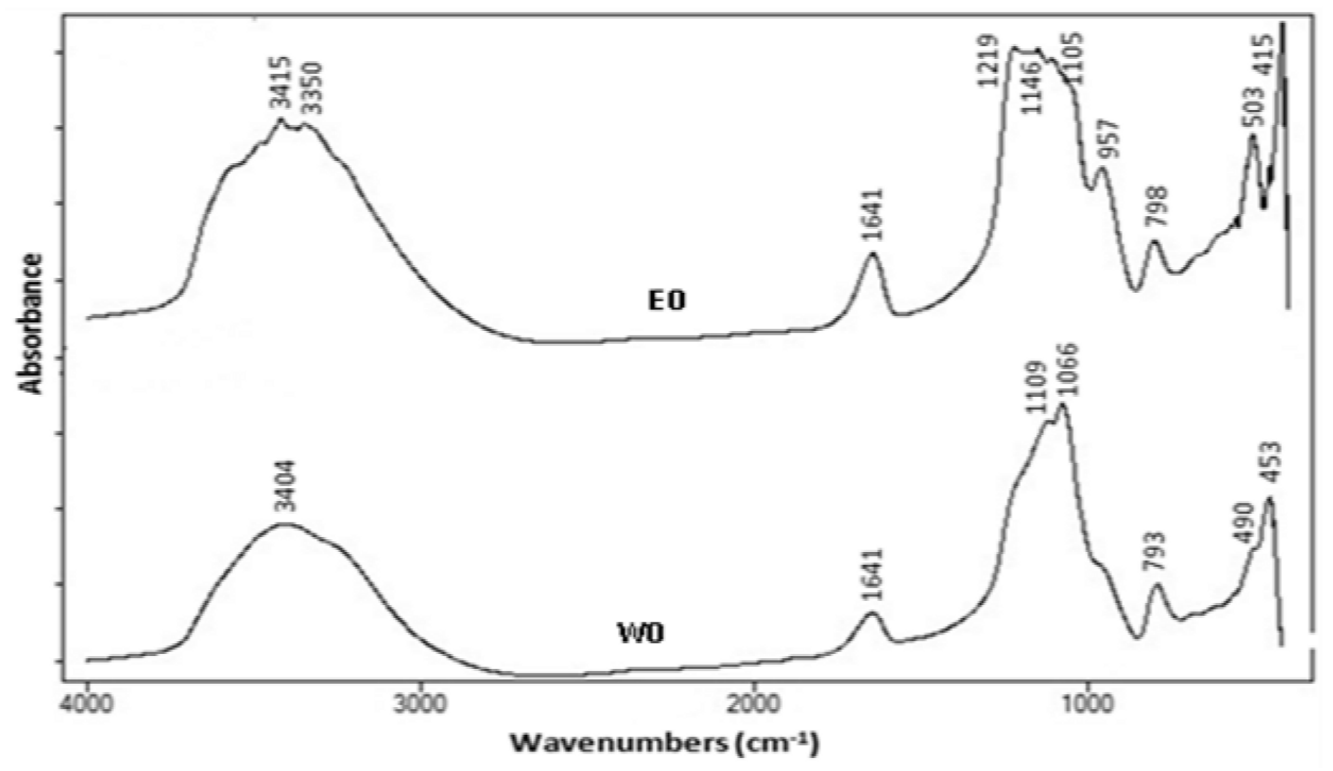

Figure 5: Infrared spectra of ore samples after 150 minutes leaching. (WO) sample from west block and (EO) sample from Petea area

veals more faster of $\mathrm{Mg}$ released from octahedral stuctures than that of Si from tetrahedral coordination. Brantley (2008) suggested that dissolution rates of silicate minerals decrease with an increase in the number of bridging oxygens. This author introduces a new term which she called "connectedness", that is a number of bridging oxygens per tetrahedral cation. Connectedness of 0 is a forsterite, 2 is a pyroxene, 2.5 is an amphibole, and 3 is a phyllosilicate and 4 is a quartz. It is inferred that dissolution rates of primary minerals would be in the reducing order: forsterite $>$ enstatite $>$ hornblende $>$ quartz. For secondary mineral, the decreasing of dissolution rates would be: serpentine/lizardite $>$ chlorite $>$ talc.

Results of XRD and FTIR analyses also show that solid residues from west block samples contain significant amount of crystalline silica (quartz), while leached residues from Petea are mainly composed of amorphous silica. The residual or amorhous silica is easily pulverized and very reactive compared to the crystalline silica. Therefore, it is a good potential to produce silicon carbide by using this residual silica as a raw material (Hirasawa and Horita, 1987).

The relatively higher dissolution rates of serpentine $(\mathrm{Mg} / \mathrm{Si}=3 / 2)$ in acid solution than that of talc $(\mathrm{Mg} / \mathrm{Si}=3 / 4)$ could be explained by con- sidering their crystal structures. In serpentine structure, one octahedral layer is bound to one tetrahedral layer. The octahedral sheet is mainly formed by $\mathrm{Mg}-\mathrm{O}$ bonds and tetrahedral sheet is occupied by $\mathrm{Si}-\mathrm{O}$ bonds. Other cations such as $\mathrm{Ni}^{2+}, \mathrm{Co}^{2+}$, and $\mathrm{Fe}^{2+}$ may replace $\mathrm{Mg}^{2+}$ in octahedral sheets. Accordingly in order to leach valuable metals from those structures, it is required for breaking the octaheral sheet without disruption of tetrahedral sheet. This feature is known as incongruent dissolution (Lin and Clemency 1981). The acid attack on octahedral sheets may takes place through both edges and gallery access mechanisms (Kaviratna and Pinnavaia 1994) (Figure 6A). In contrast, talc belong to 2:1 layer silicates in which one octahedral sheet sandwiched between two tetrahedral layers. Similarly with serpentine, octahedral sheet in talc also consists of $\mathrm{Mg}-\mathrm{O}$ bonds and tetrahedral layer mainly contains $\mathrm{Si}-\mathrm{O}$ bonds. Relatively slow dissolution rate of talc because the leach layer forms only at the edges of grain (Jurinski and Rimstidt, 2001) (Figure 6B).

It is shown that, dissolution rates of serpentine in the west ore is higher than in Petea sample. This is likely because Al content of Petea sample is higher than in west block sample. The presence of aqueous $\mathrm{Al} 3+$ has been observed to decelerate dissolution of silicates (Brantley, 

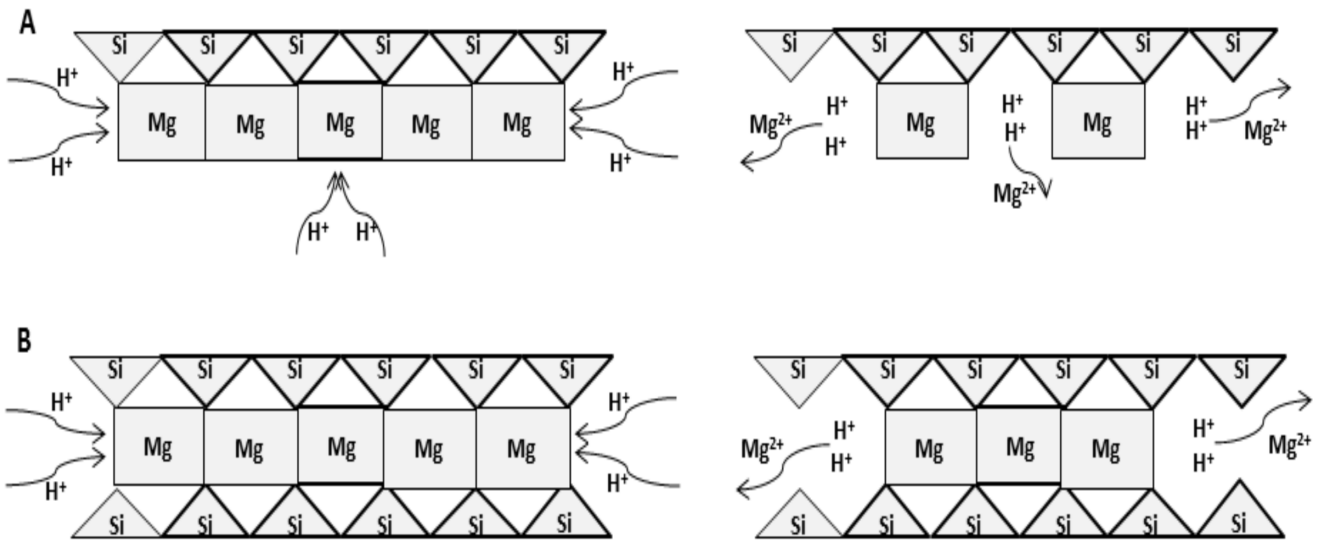

Figure 6: Schematic displaying the illustration of proton attack on octahedral sheet during the sulphuric acid leaching: (A) The exchange of $\mathrm{Mg}$ cations with 2 protons in serpentine structure may take place either via edges or gallery attack mechanism, (B) the exchange of $\mathrm{Mg}$ with 2 protons in talc structure may only occurs through edges attack mechanism (modified after Kaviratna and Pinnavaia, 1994; Saldi et al., 2007)

2008). The effect of Al-inhibition was attributed to increase adsorption of trivalent cation.

\section{Extraction of metals}

Distribution of metal extractions from the ores within the range of leaching time are shown in Figure 7. It can be seen that there are wide variation of metal recoveries throughout the experiment. In general, a better condition of metal extraction of sample WO could be achieved for 150 minutes reaction (Figure 7A). At this condition, as much as $47 \% \mathrm{Ni}, 65 \% \mathrm{Mn}, 59 \% \mathrm{Mg}$, $60 \% \mathrm{Fe}, 70 \% \mathrm{Co}$, and $79 \% \mathrm{Zn}$ could be recovered. Conversely, the extraction rates of $\mathrm{Al}$ and $\mathrm{Cr}$ at this condition is low, only about $12 \%$ and $6 \%$ respectively. In contrast, as much as $58 \%$ $\mathrm{Ni}, 58 \% \mathrm{Mn}, 74 \% \mathrm{Mg}, 50 \% \mathrm{Fe}, 48 \% \mathrm{Co}$, and $52 \% \mathrm{Zn}$ could be extracted from sample EO for 120 minutes. At this time, only around $22 \%$ $\mathrm{Al}$ and $19 \% \mathrm{Cr}$ could be recovered (Figure $7 \mathrm{~B}$ ). From these figures, it can be inferred that leaching behavior of metals in both ores were slightly different. In order to recover the higher concentration of metals from these ores, it is necessary a longer time for leaching of sample WO compared to that of sample EO. It is also expected that mostly $\mathrm{Mg}, \mathrm{Ni}$, some $\mathrm{Mn}$, and Fe extracted from sample WO was derived by dissolution of forsterite.

The complexity of minerals that appear in both ores might be one factor in inhibiting more valuable metals leached from ores mainly $\mathrm{Ni}$ and $\mathrm{Co}$ in sulfuric acid solution. The anomalous value of $\mathrm{Mg}$ leached from sample EO reveal that it is easier to release from the octahedral structure then trivalent cations from tetrahedral structure of serpentine. This confirms the study performed by Lin and Clemency (1981). On the other hand, the lower concentration of chromium in leach solution for both ores indicates that $\mathrm{Cr}$ was mainly present as oxide minerals such as magnetite/maghemite and chromite. These phases were relatively unreacted in acid solution, even after long periods of extraction (McDonald and Whittington, 2008). The lower $\mathrm{Al}$ content in leach solution also exhibit this metal has low leachability particularly when it occupies tetrahedral position in silicate structure.

Alternatively, the leachabilities of metal elements from the ores in sulphuric acid solution might also be affected by the bond strength of molecules present within minerals. The bond strength of $\mathrm{Si}-\mathrm{O}(799.6 \mathrm{~kJ} / \mathrm{mol})$ is the highest over the other moleculer functional groups in silicate structures. Al-O with bond strength $511 \mathrm{~kJ} / \mathrm{mol}$ and $\mathrm{Cr}-\mathrm{O}(461 \mathrm{~kJ} / \mathrm{mol})$ are much higher than that of $\mathrm{Fe}-\mathrm{O}(390.4 \mathrm{~kJ} / \mathrm{mol}), \mathrm{Co}-\mathrm{O}$ $(384.5 \mathrm{~kJ} / \mathrm{mol}), \mathrm{Ni}-\mathrm{O}(382.0 \mathrm{~kJ} / \mathrm{mol})$, and $\mathrm{Mg}-$ $\mathrm{O}(363.2 \mathrm{~kJ} / \mathrm{mol})$ (Lide, 2004). The lower bond 

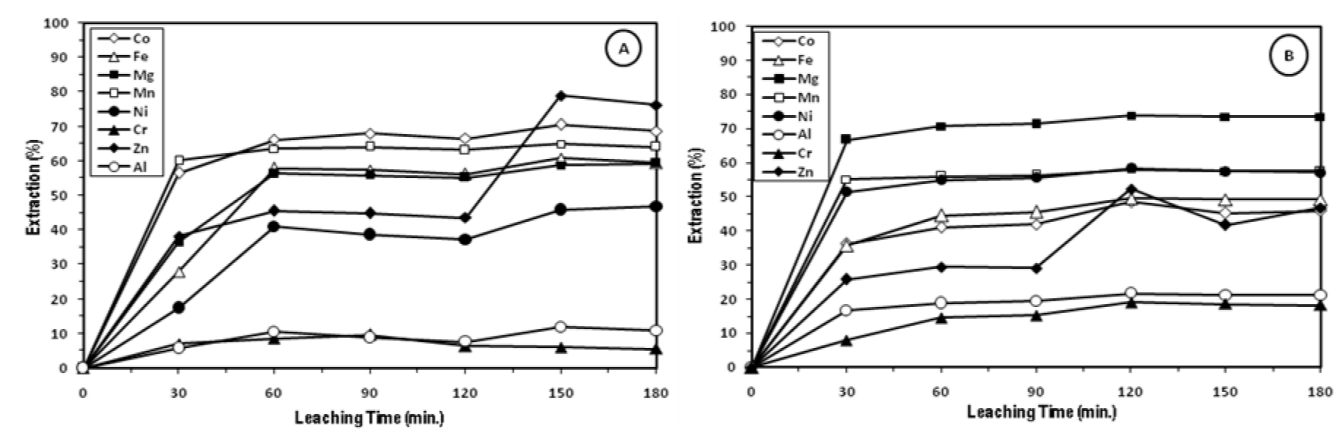

Figure 7: Graphs showing the percentage of metals extraction from Soroako Ni-laterite ores under different leaching time. A: West ore sample (WO), and B: East ore sample (EO)

strength of $\mathrm{Mg}-\mathrm{O}$ is one reason of $\mathrm{Mg}$ has the much higher solubility than other metals.

\section{Conclusions}

Mineralogical and chemical study with the ore processing implication was conducted for the Soroako saprolitic nickel ore. Based on the results from the current work, some conclusions can be drawn as follow:

1. Mineralogy of west ore (WO) is mainly composed of quartz, olivine, and pyroxene with minor talc, serpentine and spinel; whereas east ore (EO) contains principally residual serpentine with subordinate chlorite, pyroxene, amphibole, maghemite, and quartz.

2. Nickel concentration in the West Block ore is higher than that of Petea ore. Olivine, talc, serpentine and Fe/Mn-oxides are the principal Ni-bearing phases in the west ore; whereas residual serpentine (lizardite) with subordinate amounts of chlorite and amphibole are the main host minerals for $\mathrm{Ni}$ in the east ore.

3. Forsteritic olivine is the highest dissolution rate among the minerals appearing in the west ore and it indicates congruent dissolution. Conversely, the highest dissolution rate of minerals present in the east ore is serpentine, however, it seems to have incongruent dissolution.

4. About $58 \% \mathrm{Ni}$ could be extracted from east ore during two hours reaction, while only about $47 \% \mathrm{Ni}$ could be recovered from west ore and it was achieved for three hours leaching reaction.

\section{Acknowledgements}

This work is supported by the doctoral research grant from The Research Institute of Gadjah Mada University (grant no. LPPMUGM/895/BID.1/2011) and SEG Foundation (H.E. McKinstry Fund). Thanks are due to JASSO for providing scholarship during the first author conducting short term research at Department of Earth Resources Engineering, Kyushu University, Japan.

\section{References}

Ahmad, W. (2005) Mine Geology at PT. INCO, Unpublished Training Manual, ITSL Inco. Ltd, 118 p.

Barros de Oleivera, S.M, Trescases, J.J. and Melfi, A.J. (1992) Lateritic Nickel Deposits of Brazil,. Mineralium Deposita., Vol. 27, pp. $137-146$.

Brand, N.W, Butt, C.R.M., Elias, M. (1998) Nickel Laterite : classification and features., AGSO Journal of Australian Gology \& Geophysics Vol. 17, No. 4, pp. 81- 88.

Brantley, S.L. (2008) Kinetics of mineral dissolutions, (In Kinetics of Rock - Water Interaction, Editors : Brantley, S.L., Kubicki, J.D., White, A.F. ), Springer, pp. $151-210$

Elias, M. (2002) Nickel laterite deposits-a geological overview, resources and exploitation: Hobart, University of Tasmania, Centre for Ore Deposit Research Special Publication 4, p. 205-220.

Freyssinet PH, Butt, C.R.M, Morris, R.C, Piantone, P. (2005) Ore-Forming Processes Related to Lateritic Weathering., Economic Geology 100th Anniversary Volume, pp. $681-722$. 
Fuchs, Y., Linares, J., Mellini, M. (1998) Mossbauer and infrared spectrometry of lizardite-1T from Monte Fico, Elba, Physics and Chemistry of Minerals, Vol. 26, pp. $111-115$.

Glesson, S.A, Butt, C.R.M., Elias, M. (2003) Nickel Laterite: A Review, SEG Newsletter No. 54, pp. 9-16.

Glesson, S.A., Herrington, R.J., Durango, J., Velasquez, C.A. and Koll, G. (2004) The Mineralogy and Geochemistry of the Cerro Matoso S.A. Ni Laterite Deposit, Montelibano, Colombia., Economic Geology., vol. 99, pp. 1197 - 1213

Golightly, J.P. (1981) Nickeliferous Laterite Deposits., Economic Geology 75th Anniversary Volume, pp. $710-735$.

Hirasawa, R. and Horita, H. (1987) Dissolution of nickel and magnesium from garnierite ore in acid solution. Internationl Journal of Mineral Processing 19, $273-283$.

Jurinski, J.B. and Rimstidt, J.D. (2001) Biodurability of talc, American Mineralogist, Vol. 86, pp. $392-$ 399.

Kadarusman, A. Miyashita, S., Maruyama, S., Parkinson, C.D., and Ishikawa, A. (2004) Petrology, geochemistry and paleogeographic reconstruction of the East Sulawesi Ophiolite, Indonesia, Tectonophysics., vol.392, pp. $55-83$.

Kaviratna, H., Vinnavaia, T.J. (2004) Acid hydrolysis of octahedral $\mathrm{Mg}^{2+}$ sites in 2:1 layered silicates: An assessment of edge attack and gallery access mechanisms, Clay and Clay Minerals, Vol. 42, pp. $717-723$

Landers, M., Gilkes, R.J., Wells, M. (2009) Dissolution kinetics of dehydroxylated nickeliferous goethite from limonitic lateritic nickel ore., Applied Clay Science., Vol. 42, pp. 615 - 624

Lide, D.R. (2003) Handbook of Chemistry and Physics, 84th Edition, CRC Press

Lin, F.C., and Clemency, C.V., 1981, The dissolution kinetics of brucite, antigorite, talc, and phlogopite at room temperature and pressure, American Mineralogist, Vol. 66, pp. $801-806$
Liu, K., Chen, Q.Y., Hu, H.P., Yin, Z.L (2010) Characterization and leaching behavior of lizardite in Yunjiang laterite ore, Applied Clay Science, Vol. 47, pp. $311-316$

Luo, W., Feng, Q., Ou, L, Zang, G., Chen, Y. (2010) Kinetics of saprolite laterite leaching by sulphuric acid at atmospheric pressure, Mineral Engineering, Vol. 23, pp. $458-462$.

McDonald, R.G, and Whittington, B.I. (2008) Atmospheric acid leaching of nickel laterite review, Part I. Sulphuric acid technology,Hydrometallurgy,Vol. 91, pp. $33-55$.

Monnier, Ch., Girardeau, J., Maury, R.C., Cotton, J. (1995) Back-arc basin origin for the East Sulawesi Ophiolite (eastern Indonesia), Geology, Vol. 23, No. 9, pp. $851-854$.

Saldi, G.D., Kohler, S.J., Marty, N., and Oelkers, E.H. (2007) Dissolution rates of talc as a function of solution composition, $\mathrm{pH}$ and temperature, Geochemica et Cosmochimica Acta, Vol. 71, pp. 3446 $-3457$

Schellmann, W. (1989) Composition and origin of lateritic nickel ore at Tagaung Taung Burma., Mineralium Deposita., vol. 24, pp. 161 - 168.

Soeria-Atmadja, R., Golightly, J.P., Wahju, B.N. (1974) Mafic and ultramafic rock associations in the East Arc of Sulawesi. Proceedings ITB Vol. 8, No. 2.

Sontevska, V., Jovanovski, G., Makreski, P. (2007) Mineral from Macedonia. Part XIX. Vibrational spectroscopy as identificational tool for some sheet silicate minerals, Journal of Molecular Structure, Vol. 834 - 836, pp. 328-327.

Thorne R., Herrington, R., and Roberts, S. (2009) Composition and origin of the Caldag oxide nickel laterite, W. Turkey., Mineralium Deposita, vol. 44, pp. $581-595$.

Wolff-Boenich, D., Gislason, S.R., Oelkers, E.H. (2006) The effect of crystallinity on dissolution rates and $\mathrm{CO} 2$ consumption capacity of silicates, Geochimica et Cosmochimica Acta Vol. 70, pp. 858-870. 